\title{
Preparation, Characterization and Electrochemical Studies of Dinuclear Copper(II) Complexes with Pseudohalides and Bidentate Amines on Platinum Electrode in Acetonitrile
}

\author{
V. Sargentelli, , A.V. Benedetti, and A.E. Mauro \\ Instituto de Química de Araraquara, UNESP, C.P. 355, \\ 14801-970 Araraquara - SP, Brazil
}

Received: June 30, 1996; December 5, 1996

\begin{abstract}
Preparação, caracterização e o comportamento eletroquímico dos complexos: $\left[\mathrm{Cu}\left(\mathrm{N}_{3}\right)_{2}(\mathrm{~N}, \mathrm{~N} \text {-diEten })\right]_{2},\left[\mathrm{Cu}\left(\mathrm{N}_{3}\right)_{2}(\text { tmeen })\right]_{2},\left[\mathrm{Cu}\left(\mathrm{N}_{3}\right)(\mathrm{NCO})(\mathrm{N}, \mathrm{N} \text {-diEten })\right]_{2}$, $\left[\mathrm{Cu}\left(\mathrm{N}_{3}\right)_{2}\left(\mathrm{~N}, \mathrm{~N}^{\prime} \text {-diMeen }\right)\right]_{2}$ e $\left[\mathrm{Cu}\left(\mathrm{N}_{3}\right)(\mathrm{NCO})(\text { tmeen })\right]_{2}$ são apresentados e discutidos. Os estudos eletroquímicos foram realizados utilizando-se as técnicas de voltametria cíclica e eletrólise a potencial controlado. Os voltamogramas cíclicos de todos complexos são semelhantes e apresentam um par de picos de corrente entre - 0,65 e 0,0 V. A eletrólise a potencial controlado, $\mathrm{em} \cong-0,55 \mathrm{~V}$, forneceu $1,8<\mathrm{n}<2,1$ para todos os compostos, indicando a redução de $\mathrm{Cu}(\mathrm{II})$ a $\mathrm{Cu}(\mathrm{I})$ em ambos os centros metálicos. A comparação dos valores dos potenciais de pico do par $\mathrm{Cu}(\mathrm{II}) / \mathrm{Cu}(\mathrm{I})$ desses complexos mostra que esse processo redox é fracamente influenciado pela basicidade dos ligantes.
\end{abstract}

The complexes: $\left[\mathrm{Cu}\left(\mathrm{N}_{3}\right)_{2}(\mathrm{~N}, \mathrm{~N}-\text { diEten })\right]_{2},\left[\mathrm{Cu}\left(\mathrm{N}_{3}\right)_{2}(\mathrm{tmeen})\right]_{2},\left[\mathrm{Cu}\left(\mathrm{N}_{3}\right)(\mathrm{NCO})(\mathrm{N}, \mathrm{N}-\mathrm{diEten})\right]_{2}$, $\left[\mathrm{Cu}\left(\mathrm{N}_{3}\right)_{2}\left(\mathrm{~N}, \mathrm{~N}^{\prime} \text {-diMeen }\right]_{2}\right.$ and $\left[\mathrm{Cu}\left(\mathrm{N}_{3}\right)(\mathrm{NCO})(\text { tmeen })\right]_{2}$ were prepared, characterized and their electrochemical behavior was investigated by cyclic voltammetry and controlled potential electrolysis. Cyclic voltammograms for all complexes studied are similar and exhibit one pair of current peaks in the range of -0.65 to $+0.0 \mathrm{~V}$. The number of electrons obtained from controlled potential electrolysis at $c a$. $-0.55 \mathrm{~V}$ for all compounds was $1.8 \AA \mathrm{n} \circledast 2.1$, indicating that both copper(II) metallic centres in the molecule were reduced to copper (I). Comparing the peak potential values for these complexes one can observe that the redox process corresponding to copper(II)/copper(I) couple is slightly influenced by the $\sigma$-basicity of the ligands.

Keywords: copper complexes, $N^{\prime}, N^{\prime}$-dialkyldiamine ligands, pseudohalyde ligands, cyclic voltammetry of copper complexes

\section{Introduction}

The copper (II) complexes containing pseudohalide ligands have gained much importance in recent years considering that their redox properties can contribute to better understanding of the structure and function of copper proteins $^{1-3}$. Although a number of examples are available in the literature regarding cyclic voltammetric studies of dinuclear copper(II) complexes with different donor sites ${ }^{4-9}$, as far as we know, there is no information about the electrochemical behavior of dinuclear copper(II) compounds containing pseudohalides and bidentate amine ligands.

* Present address: Departamento de Ciências da Universidade de Marília UNIMAR
We are interested in understanding the electrochemical behavior of the complexes: $\left[\mathrm{Cu}\left(\mathrm{N}_{3}\right)_{2}(\mathrm{~N}, \mathrm{~N}-\mathrm{diEten})\right]_{2}(\mathbf{I})$, $\left[\mathrm{Cu}\left(\mathrm{N}_{3}\right)_{2}(\text { tmeen })\right]_{2},(\mathbf{I I}),\left[\mathrm{Cu}\left(\mathrm{N}_{3}\right)(\mathrm{NCO})(\mathrm{N}, \mathrm{N}-\text { diEten })\right]_{2}$ (III), $\left[\mathrm{Cu}\left(\mathrm{N}_{3}\right)_{2}\left(\mathrm{~N}, \mathrm{~N}^{\prime}-\text { diMeen) }\right]_{2}(\mathrm{IV})\right.$ and $\left[\mathrm{Cu}\left(\mathrm{N}_{3}\right)(\mathrm{NCO})\right.$ (tmeen) $]_{2}(\mathrm{~V})$; where $\mathrm{N}, \mathrm{N}$-diEten $=\mathrm{N}, \mathrm{N}$-diethylethylenediamine; N,N'-diMeen $=\mathrm{N}, \mathrm{N}^{\prime}$-dimethylethylenediamine and tmeen $=\mathrm{N}, \mathrm{N}, \mathrm{N}^{\prime}, \mathrm{N}^{\prime}$ - tetramethylethylenediamine, and then determine the influence of the ligands on the redox potential of the metallic centre. In this work we report the electrochemical results for these complexes, in deaerated acetonitrile solution containing $0.5 \mathrm{M}$ $\mathrm{NaClO}_{4}$, obtained by means of cyclic voltammetry and 
controlled potential electrolysis. The preparation and characterization of the complexes (IV) and (V) are also discussed.

\section{Experimental}

Synthesis and characterization of the copper complexes

The compounds (I), (II) and (III) were prepared and characterized as previously described ${ }^{10-12}$. For these complexes the copper(II) content, determined by complexometric titration with standard EDTA solution, using PAN $0.05 \%$ in ethanol as indicator ${ }^{13}$, and the elemental analysis of $\mathrm{C}, \mathrm{H}$ and $\mathrm{N}$ were in agreement with the literature.

The compounds (IV) and (V) were obtained for the first time in our laboratory. The complexe (IV) was prepared by dropwise addition, with stirring, of a solution of $\mathrm{NaN}_{3}$ $(3.00 \mathrm{mmol})$ in a solution containing $\mathrm{Cu}\left(\mathrm{NO}_{3}\right)_{2} .3 \mathrm{H}_{2} \mathrm{O}(3.00$ $\mathrm{mmol})$ and $\mathrm{N}, \mathrm{N}$-diEten $(2.82 \mathrm{mmol})$ in ethanol. When the precipitation was completed the solution was filtered and the product washed with diethyl ether and finally dried in vacuo. Found: Cu 26,68; C 20,57; N 48,15; H 5,10\%. Calc.: Cu 26,98; C 20,38; N 47,53; H 5,13\%. Complex (V) was prepared by a similar procedure. Found: $\mathbf{C u} 23,85 ; \mathbf{C}$ 32,50; N 32,08; H 5,98\%. Calc.: Cu 24,09; C 31,87; N 31,86; H 6,06\%.

The infrared spectra were recorded on a Nicolet 730 SX-FT spectrophotometer using CsI pellets.

\section{Electrochemical measurements}

Electrochemical measurements were performed with a PAR Model 273A potentiostat/galvanostat equipped with a $\mathrm{X}-\mathrm{Y}$ recorder. Cyclic voltammograms were recorded in acetronitrile solutions containing $0.5 \mathrm{M} \mathrm{NaClO}_{4}$ as supporting electrolyte at room temperature. The 1-3 mM sample solutions were purged with dry and purified argon before each experiment. A conventional electrochemical cell having a platinum disc $\left(\mathrm{A}_{\text {geom }}=0.2 \mathrm{~cm}^{2}\right)$ as working electrode, a platinum-wire as counter electrode and an $\mathrm{Ag} / \mathrm{AgNO}_{3}\left(10^{-2} \mathrm{M}\right)$ as reference electrode was employed. At the end of each experiment, ferrocene was added as internal reference. Under this condition the peak potential for $\mathrm{F}_{\mathrm{ec}} \otimes \mathrm{F}_{\mathrm{ec}}{ }^{+}+\mathrm{e}^{-}$reaction was located at $0.04 \mathrm{~V}$. For controlled potential electrolysis a network platinum was used as working electrode.

\section{Results and Discussion}

The crystal structure analysis of the compounds (I) (III) and the IR spectrum of compound (I) have already been reported and discussed elsewhere. ${ }^{10-12}$ Pseudohalide complexes (IV) and (V) may have either monomeric or dimeric structures. The main bands in the infrared spectra of the complexes (IV) and (V) are listed with their descrip-
Table 1. Infrared spectra $\left(4000-200 \mathrm{~cm}^{-1}\right)$.

\begin{tabular}{|c|c|c|}
\hline complex & vibrational frequency, $\mathrm{cm}^{-1}$ & Assignment \\
\hline \multicolumn{3}{|l|}{ (IV) } \\
\hline & $3305 m, 3256 m$ & $v \mathrm{NH}$ \\
\hline & $2947 m, 2990 w, 2856, m$ & $v \mathrm{CH}_{2}, \mathrm{CH}_{3}$ \\
\hline & $2056 v s, 2034 v s$ & $v_{\text {as }} \mathrm{N}_{3}$ \\
\hline & $755 m, 602 m, 561 m$ & $\delta \mathrm{N}_{3}$ \\
\hline & $499 w, 426 s h, 376 m$ & $v \mathrm{Cu}-\mathrm{N}$ \\
\hline \multicolumn{3}{|l|}{ (V) } \\
\hline & $2987 m, 2908 m, 2796 m$ & $v \mathrm{CH}_{3}$ \\
\hline & $2236 v s$ & $v_{\text {as }} \mathrm{NCO}$ \\
\hline & $2052 v s$ & $\mathrm{v}_{\mathrm{as}} \mathrm{N}_{3}$ \\
\hline & $1473 w$ & $\delta \mathrm{CH}_{3}$ \\
\hline & $480 w, 430 \mathrm{sh}, 330 \mathrm{~m}$ & $v \mathrm{Cu}-\mathrm{N}$ \\
\hline
\end{tabular}

$v s=$ very strong, $s=$ strong, $m=$ medium, $s h=$ shoulder.

tions and assignments in Table 1. The infrared spectra of these complexes are similar and show absorption bands characteristic for the amines coordinated to copper (II) ${ }^{14}$. Furthermore, bands corresponding to the vibrational modes of pseudohalide groups are also present in the spectra and have been assigned for each complex. The values listed for pseudohalide bands in Table 1 support the presence in complex (IV) of terminal and bridging end-on azides. For the complex (V) the results suggest a unique coordination mode for cyanate and azide. This particular complex may be a dimeric compound with terminal $\mathrm{N}$-bonded cyanate and bridge end-on azide. Thus, these brief comments of the spectroscopy data allow us to predict that the copper ions in the compounds (IV) and (V) are in a five coordinate environment and the complexes have dimeric structures.

For the blank solution no anodic or cathodic peaks in the potential range from. -1.2 to $+2.0 \mathrm{~V}$ were observed. The cyclic voltammogram of dried $\mathrm{Cu}\left(\mathrm{ClO}_{4}\right)_{2}$ (green solution) depicts a cathodic current peak at $0.4 \mathrm{~V}$ and an anodic current peak at $0.8 \mathrm{~V}$. This pair of peaks is possibly due to the $\mathrm{Cu}(\mathrm{II}) / \mathrm{Cu}(\mathrm{I})$ redox process. At more negative potentials another pair of current peaks at -1 and $-0.5 \mathrm{~V}$ is observed, which was attributed to $\mathrm{Cu}(\mathrm{I}) / \mathrm{Cu}(0)$ redox process. The free azide ligand does not show any current peak in the potential range from -0.8 to $+1.5 \mathrm{~V}$, but an anodic current peak is observed at $1.7 \mathrm{~V}$, probably due to the azide oxidation to form $\mathrm{N}_{2}$. The $\mathrm{N}, \mathrm{N}$-diEten ligand exhibits two anodic current peaks at 0.92 and $1.38 \mathrm{~V}$, the N,N'-diMeen shows only one anodic current peak at $0.9 \mathrm{~V}$ and tmeen exhibits two anodic current peaks at $0.97 \mathrm{~V}$ and $1.31 \mathrm{~V}$, indicating that the diamine oxidation is an irreversible process. For these ligands no cathodic current peaks are observed in the 
potential range studied. For solutions containing $\mathrm{Cu}\left(\mathrm{ClO}_{4}\right)_{2}+\mathrm{NaN}_{3}$ the main cathodic and anodic current peaks are observed at 0.56 and $0.71 \mathrm{~V}$, respectively. The color of the solution is yellow probably due to the formation of a copper-azide complex. The complex formation is responsible for the shift in the peak potential values in relation to the copper one. The copper(II)/azide system has been investigated by Neves and coworkers using spectrophotometric and potentiometric measurements in aqueous solution ${ }^{15-18}$. The results show that there are many anionic and cationic species in solution depending on the ligand concentration. Unfortunately a direct comparison among the results obtained by Neves and coworkers and this work is not valid because of the different media used. Further electrochemical investigations of this system in non-aqueous solution are in progress in our laboratory. For $\mathrm{Cu}\left(\mathrm{ClO}_{4}\right)_{2}$ plus amine-containing solution (blue color) a well-formed cathodic current peak is observed at $-0.15 \mathrm{~V}$,

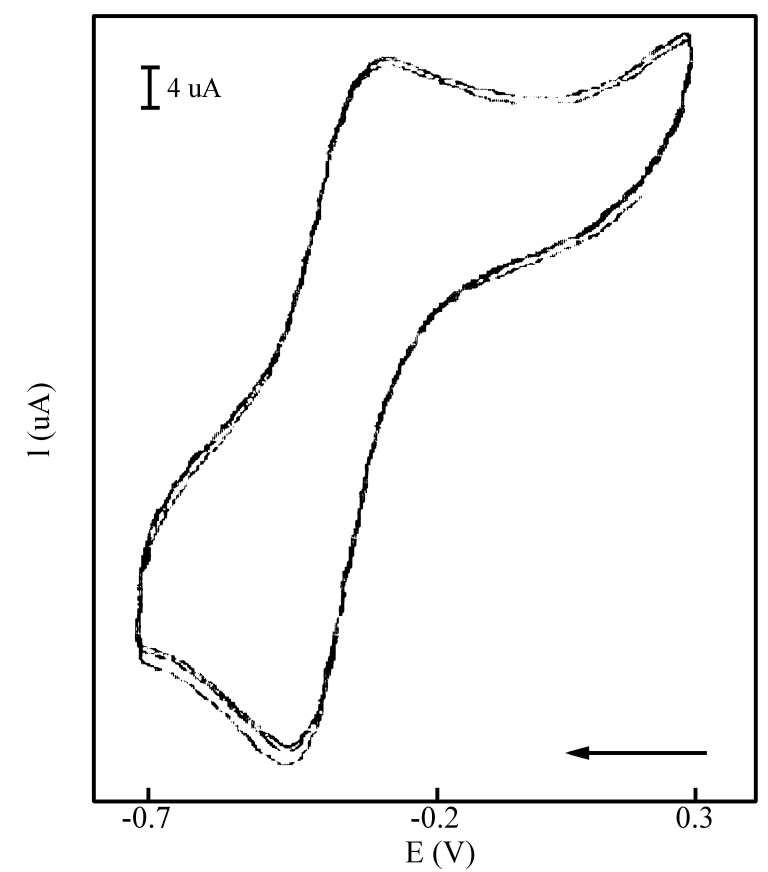

Figure 1. Cyclic voltammogram of $\left[\mathrm{Cu}\left(\mathrm{N}_{3}\right)_{2}(\mathrm{~N}, \mathrm{~N}-\text { diEten })\right]_{2}$ in acetonitrile containing $0.5 \mathrm{M} \mathrm{NaClO}_{4}$ and $1.310^{-3} \mathrm{M}$ of the complex, $\mathrm{v}=0.3 \mathrm{~V} \mathrm{~s}^{-1}$, at $25^{\circ} \mathrm{C}$. which can be related to the reduction of $\mathrm{Cu}$ (II)- to $\mathrm{Cu}(\mathrm{I})$-amine complex.

Cyclic voltammograms for all complexes studied are similar and exhibit one pair of current peaks in the range of -0.65 to $+0.0 \mathrm{~V}$ (see Fig. 1). Since the free ligands and copper(II) ions do not show any current peaks in this region, the observed current peaks must be related to the metal-centre of the complex. The anodic and cathodic peak potential values are shifted in the anodic and cathodic direction respectively as $\mathrm{v}$ increases, leading therefore, to an increase in the potential difference, $\Delta \mathrm{Ep}$. The ratio of the anodic and cathodic current peaks is close to unity. These results suggest a quasi-reversible electrode process having no coupled chemical reaction. The number of electrons obtained from controlled potential electrolysis at $c a .-0.55 \mathrm{~V}$ for all the compounds was $1.8 \AA \mathrm{n} \circledast 2.1$, indicating that both copper (II) centres in the complexes were reduced to copper (I).

The data obtained from the cyclic voltammograms for the complexes (I), (II), (III), (IV) and (V) in the range from $-0.8 \mathrm{~V}$ to $1.0 \mathrm{~V}$, at $200 \mathrm{mV} / \mathrm{s}$, are summarized in Table 2 .

Comparison of the potential values for complexes (I), (II) and (IV), where only the amine ligand was changed, shows

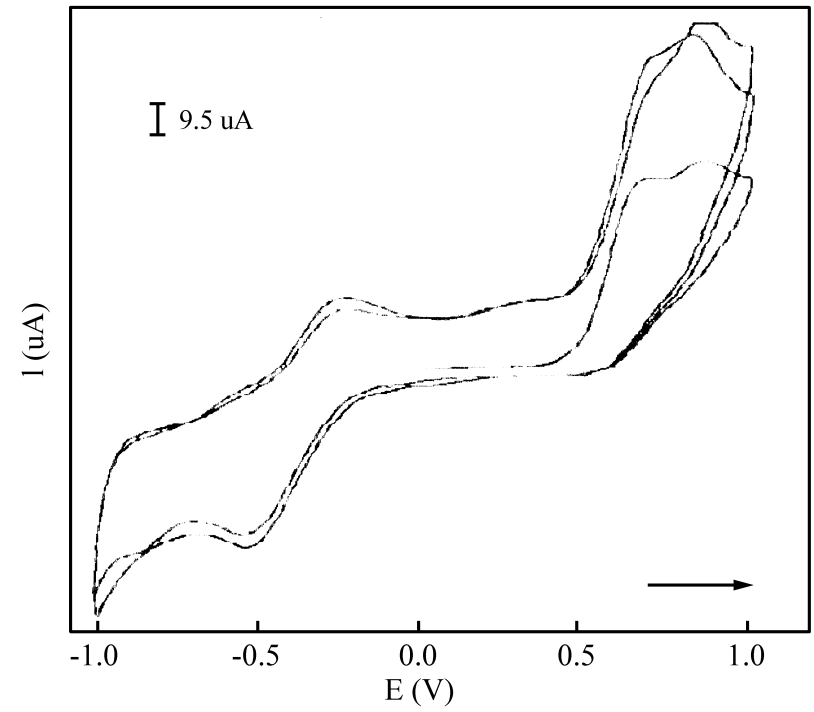

Figure 2. Cyclic voltammogram of $\left[\mathrm{Cu}\left(\mathrm{N}_{3}\right)_{2}(\mathrm{~N}, \mathrm{~N}-\text { diEten })\right]_{2}$ in acetonitrile containing $0.5 \mathrm{M} \mathrm{NaClO}_{4}$ and $1.310^{-3} \mathrm{M}$ of the complex, $\mathrm{y}=0.2 \mathrm{~V} \mathrm{~s}^{-1}$, at $25^{\circ} \mathrm{C}$.

Table 2: Data obtained from the cyclic voltammograms for the complexes.

\begin{tabular}{lcccccc}
\hline complex & $\mathrm{E}_{\mathrm{pc} 1}(\mathrm{~V})$ & $\mathrm{E}_{\mathrm{pa} 2}(\mathrm{~V})$ & $\Delta \mathrm{Ep}$ & $\mathrm{I}_{\mathrm{pa}} / \mathrm{I}_{\mathrm{pc}}$ & $\mathrm{E}_{\mathrm{pa} 2}(\mathrm{~V})$ & $\mathrm{E}_{\mathrm{pa} 3}(\mathrm{~V})$ \\
\hline (I) & -0.46 & -0.23 & 0.23 & 0.9 & 0.64 & 0.84 \\
(II) & -0.43 & -0.14 & 0.29 & 1.1 & 0.60 & 0.80 \\
(III) & -0.50 & -0.20 & 0.30 & 0.8 & 0.70 & 0.86 \\
(IV) & -0.45 & -0.33 & 0.12 & 0.8 & 0.63 & 0.79 \\
(V) & -0.40 & -0.13 & 0.27 & 1.3 & 0.71 & 0.85 \\
\hline
\end{tabular}


that the peak potential values do not differ significantly, however complex (II) shows the least negative potential for reduction of a metal centre $(-0.43 \mathrm{~V})$. In the case of complexes (III) and $(\mathbf{V})$ complex $(\mathbf{V})$ has the least negative potential value. This fact can be attributed to the lower $\sigma$-basicity of the amine tmeen. Thus, as the electron density on the metal ion decreases the reduction potential becomes less negative.

All the complexes also exhibited two more anodic current peaks in the potential range from 0.6 to $0.9 \mathrm{~V}$ located at $\cong 0.6$ and $0.8 \mathrm{~V}$. The corresponding cathodic current peaks were not observed (see Fig. 2). The number of electrons obtained from controlled potential electrolysis at $0.9 \mathrm{~V}$ for the compounds was $3.6 \AA \mathrm{n} \circledast 4$ 4.1. The IR spectra of the electrolysis product was recorded in $\mathrm{KBr}$ pellets and the absorption bands corresponding to coordinated azides ligands were observed. These observations suggest that anodic current peaks observed at more positive potential can be related to the irreversible oxidation of copper(II) complexes to copper(III) complexes.

\section{Acknowledgments}

The financial assistance of the Conselho Nacional de Desenvolvimento Científico e Tecnológico - CNPq and Fundação de Amparo à Pesquisa do Estado de São Paulo FAPESP is gratefully acknowledged. One of the authors (V. Sargentelli) is also grateful to $\mathrm{CNPq}$ and Fundação Coordenação de Aperfeiçoamento de Pessoal de Nível Superior - CAPES, Brazil for Ph.D. scholarship.

\section{References}

1. Mclachalan, G.A.; Fallon, G.D.; Marin, R.L.; Spiccia, L. Inorg. Chem. 1995, 34, 254.

2. Sabolovic, J.; Rasmussen, K. Inorg. Chem. 1995, 34, 1221.

3. Tuczek, F.; Bensch, W. Inorg. Chem. 1995, 34, 1482.
4. Oshio, H.; Toriumi, K.; Hayashi, Y. J. Chem. Soc. Dalton Trans. 1990, 293.

5. Su, C.-C.; Chen, J.-H.; Hwang, K.-Y.; Liu, S.-J.; Wang, S.-W.; Wang, S.-L.; Liu, S.-N. Inorg. Chim. Acta 1992, 196, 231.

6. Daniele, S.; Pena, M.J. Electrochim. Acta 1993, $38,165$.

7. Tsiamis, C.; Jannakoudakis, P.D.; Sachsinger, N.; Hennig, H. Electrochim. Acta 1993, 38, 2623.

8. Mohamadou, A.; Déchamps-Oliver, I.; Barbier, J. Polyhedron 1994, 13, 3277.

9. Das, N.N.; Dash, A.C. Polyhedron 1995, 14, 1221.

10. Casagrande Jr., O.L.; Klein, S.I.; Mauro, A.E.; Tomita, K. Trans. Met. Chem. 1989, 14, 45.

11. Bkouche-Wasksman, I.; Sikorav, S.; Kahn, O. J. Crystall. and Spec. Research. 1983, 13, 303.

12. De Simone, C.A. Cristalografia de Alguns Compostos Organo-Sintéticos e Complexos de Transições $f$ e d por Difração de Raios X; Ph.D. Thesis, Instituto de Física e Química de São Carlos-USP, 1989.

13. Flaska, C. In EDTA Titration - An Introduction and Practice; Pergamon Press, New York, 1967.

14. Nakamoto, K. In Infrared Spectra of Inorganic and Coordination Compounds; John Wiley \& Sons, New York, 1986.

15. Senise, P.; Neves, E.A. J. Am. Chem. Soc. 1961, $83,4146$.

16. Neves, E.A. J. Inorg. Nucl. Chem. 1971, 33, 571.

17. Senise, P.; Neves, E.A. J. Inorg. Nucl. Chem. 1971, 33, 351 .

18. Neves, E.A.; De Andrade, J.F.; Chierice, G.O. Anal. Chim. Acta 1983, 155, 269.

FAPESP helped in meeting the publication costs of this article 